\title{
The Formation of Sulfate and Elemental Sulfur Aerosols under Varying Laboratory Conditions: Implications for Early Earth
}

\author{
H. Langley DeWitt, ${ }^{1,2}$ Christa A. Hasenkopf, ${ }^{2,3}$ Melissa G. Trainer, ${ }^{4}$ Delphine K. Farmer, ${ }^{2}$ \\ Jose L. Jimenez, ${ }^{1,2}$ Christopher P. McKay, ${ }^{5}$ Owen B. Toon, ${ }^{3}$ and Margaret A. Tolbert, ${ }^{1,2}$
}

\begin{abstract}
The presence of sulfur mass-independent fractionation (S-MIF) in sediments more than $2.45 \times 10^{9}$ years old is thought to be evidence for an early anoxic atmosphere. Photolysis of sulfur dioxide $\left(\mathrm{SO}_{2}\right)$ by UV light with $\lambda<220 \mathrm{~nm}$ has been shown in models and some initial laboratory studies to create a S-MIF; however, sulfur must leave the atmosphere in at least two chemically different forms to preserve any S-MIF signature. Two commonly cited examples of chemically different sulfur species that could have exited the atmosphere are elemental sulfur $\left(\mathrm{S}_{8}\right)$ and sulfuric acid $\left(\mathrm{H}_{2} \mathrm{SO}_{4}\right)$ aerosols. Here, we use real-time aerosol mass spectrometry to directly detect the sulfur-containing aerosols formed when $\mathrm{SO}_{2}$ either photolyzes at wavelengths from 115 to $400 \mathrm{~nm}$, to simulate the UV solar spectrum, or interacts with high-energy electrons, to simulate lightning. We found that sulfurcontaining aerosols form under all laboratory conditions. Further, the addition of a reducing gas, in our experiments hydrogen $\left(\mathrm{H}_{2}\right)$ or methane $\left(\mathrm{CH}_{4}\right)$, increased the formation of $\mathrm{S}_{8}$. With UV photolysis, formation of $\mathrm{S}_{8}$ aerosols is highly dependent on the initial $\mathrm{SO}_{2}$ pressure; and $\mathrm{S}_{8}$ is only formed at a $2 \% \mathrm{SO}_{2}$ mixing ratio and greater in the absence of a reductant, and at a $0.2 \% \mathrm{SO}_{2}$ mixing ratio and greater in the presence of $1000 \mathrm{ppmv}$ $\mathrm{CH}_{4}$. We also found that organosulfur compounds are formed from the photolysis of $\mathrm{CH}_{4}$ and moderate amounts of $\mathrm{SO}_{2}$. The implications for sulfur aerosols on early Earth are discussed. Key Words: S-MIF-Archean atmosphere-Early Earth—Sulfur aerosols. Astrobiology 10, 773-781.
\end{abstract}

\section{Introduction}

U NDERSTANDING THE ATMOSPHERE of early Earth during the Archean, the period of time approximately 4-2.45 billion years ago, is an important part of understanding the conditions under which life originated and developed. Not much is known with certainty about the atmosphere during the Archean. However, various pieces of geological evidence provide guidelines toward the atmospheric composition and Earth's climate at the time when life emerged on Earth.

It is thought that a major change in the oxidative state of early Earth's atmosphere occurred at the end of the Archean, approximately $2.45 \mathrm{Ga}$ (Bekker et al., 2004, and references therein), with perhaps the strongest evidence coming from isotopic patterns seen in S-bearing sediments through time (Farquhar et al., 2000). Sulfur is emitted from volcanic ac- tivity as either hydrogen sulfide $\left(\mathrm{H}_{2} \mathrm{~S}\right)$ or sulfur dioxide $\left(\mathrm{SO}_{2}\right)$ and readily converts between the two different starting species in a reducing atmosphere (Kasting et al., 1989). Around $2 \mathrm{ppbv}, \mathrm{SO}_{2}$ could have existed in the reducing atmosphere of early Earth if the volcanic outgassing rate was three times as high as it is today, assuming the ocean was saturated with $\mathrm{SO}_{2}$ and thus rainout was not a loss process for $\mathrm{SO}_{2}$ (Kasting et al., 1989). Measurements show that sulfur mass-independent fractionation (S-MIF) occurs in sedimentary rocks older than $2.45 \mathrm{Ga}$. However, all the S-isotopes fall along a mass-dependent fractionation line in younger sediments (Farquhar et al., 2000). An anoxic early Earth atmosphere could help explain these data (Pavlov and Kasting, 2002).

Laboratory experiments (Farquhar et al., 2001) and model simulations (Lyons, 2007) suggest that the photolysis of $\mathrm{SO}_{2}$

\footnotetext{
${ }^{1}$ Department of Chemistry and Biochemistry, University of Colorado at Boulder, Boulder, Colorado.

${ }^{2}$ Cooperative Institute for Research in the Environmental Sciences, University of Colorado at Boulder, Boulder, Colorado.

${ }^{3}$ Department of Atmospheric and Oceanic Sciences, Laboratory for Atmospheric and Space Physics, University of Colorado at Boulder, Boulder, Colorado.

${ }^{4}$ NASA Goddard Space Flight Center, Greenbelt, Maryland.

${ }^{5}$ Space Science Division, NASA Ames Research Center, Moffett Field, California.
} 
by UV light with a wavelength $<220 \mathrm{~nm}$ at low altitudes is one way to form the S-MIF found in the Archean sediments. For these wavelengths of UV light to reach the lower atmosphere, an anoxic early Earth atmosphere would have been necessary (Farquhar et al., 2001). The formation of S-MIF below $10 \mathrm{~km}$ is believed to be necessary for the efficient fallout of these S-MIF-bearing species to reach the ground (Domagal-Goldman et al., 2008). Ozone $\left(\mathrm{O}_{3}\right)$ and oxygen $\left(\mathrm{O}_{2}\right)$ in the current stratosphere absorb the lower-wavelength incoming solar radiation and prevent the wavelengths of light necessary to form S-MIF from reaching the lower atmosphere. The preservation of the S-MIF signals in the geological record requires the formation of at least two types of S-bearing species with different oxidative states (Kasting, 2001). The different sulfur reservoirs must be spatially and temporally separated to preserve the S-MIF signal (Pavlov and Kasting, 2002). $\mathrm{H}_{2} \mathrm{SO}_{4}$ and elemental sulfur (specifically $\mathrm{S}_{8}$ ) aerosols formed from the photolysis and subsequent reactions of $\mathrm{SO}_{2}$ are often cited as two possible reservoirs for SMIF (Kasting et al., 1989; Ono et al., 2003; Zahnle et al., 2006; Domagal-Goldman et al., 2008). To achieve these two distinct sulfur reservoirs, it has been proposed that an extremely anoxic atmosphere is necessary, as the presence of oxygen at $10^{-5}$ times the present atmospheric level (PAL) would eventually cause all the sulfur in the atmosphere to become $\mathrm{H}_{2} \mathrm{SO}_{4}$ (Pavlov and Kasting, 2002).

The chemical mechanisms used in model predictions of the relative concentrations of different types of sulfurcontaining aerosols often contain unknown and uncertain rate constants that may affect the results of the model (Kasting et al., 1989; Pavlov and Kasting, 2002). Previous experimental work on S-MIF formation from low-wavelength photolysis by Farquhar et al. (2001) was performed at high levels of $\mathrm{SO}_{2}$, approximately $1-2 \% \mathrm{SO}_{2}$ in carbon dioxide $\left(\mathrm{CO}_{2}\right)$ with, and without, added water $\left(\mathrm{H}_{2} \mathrm{O}\right)$. At these levels of $\mathrm{SO}_{2}$, both $\mathrm{S}_{8}$ and $\mathrm{H}_{2} \mathrm{SO}_{4}$ aerosols were formed. However, these levels are significantly higher than those believed to have been present on early Earth (Kasting et al., 1989). A model study by Ono et al. (2003) found that the amount of $\mathrm{SO}_{2}$ greatly influenced the $\mathrm{S}_{8} / \mathrm{H}_{2} \mathrm{SO}_{4}$ ratio, with $\mathrm{S}_{8}$ composing about $50 \%$ of the total S-bearing aerosol mass formed at an $\mathrm{SO}_{2}$ outgassing flux of $3.5 \times 10^{9}$ molecules $\mathrm{cm}^{-2} \mathrm{~s}^{-1}$, while almost no $\mathrm{S}_{8}$ was formed at an $\mathrm{SO}_{2}$ outgassing rate an order of magnitude lower. Later models have probed the effects of other major atmospheric constituents on sulfur aerosol chemistry. Zahnle et al. (2006) used a 1-D model to study the formation of $\mathrm{S}_{8}$ from photochemical reactions of $\mathrm{O}_{2}$, methane $\left(\mathrm{CH}_{4}\right)$, and $\mathrm{SO}_{2}$ in the atmosphere. They found that efficient $\mathrm{S}_{8}$ production at $\mathrm{O}_{2}$ levels of $10^{-7} \mathrm{PAL}$ or lower requires the presence of reduced gases (i.e., $\mathrm{CH}_{4}$ or hydrogen, $\mathrm{H}_{2}$ ). With a fixed $\mathrm{O}_{2}$ level of $10^{-7} \mathrm{PAL}$, they found that $\mathrm{S}_{8}$ production shuts off for $\mathrm{CH}_{4}<8$ ppmv. Increasing the $\mathrm{CH}_{4}$ mixing ratio allowed $\mathrm{S}_{8}$ to form at higher $\mathrm{O}_{2}$ levels (Zahnle et al., 2006). Significant amounts of $\mathrm{CH}_{4}$ could have come from early methanogens. Ono et al. (2003) found a similar positive correlation in their model with the atmospheric pressure of $\mathrm{CH}_{4}$ and the formation of $\mathrm{S}_{8}$. Other forms of S-bearing aerosols, such as organosulfur (a general term for species containing $\mathrm{C}$ and $\mathrm{S}$ ), could also have been present under the atmospheric conditions of early Earth and may have helped preserve S-MIF signal (Lyons, 2009; Ueno et al., 2009).
Here, we report the results of laboratory experiments to probe the formation of different chemical forms of sulfurcontaining aerosols through UV radiation (to produce aerosols from photolysis from solar radiation) and electrical discharge (to simulate lightning). We used real-time aerosol mass spectrometry to probe the chemical composition of sulfur aerosols formed from a mixture of $\mathrm{CH}_{4} / \mathrm{CO}_{2} / \mathrm{H}_{2}$ with $\mathrm{SO}_{2}$. The effect of the initial partial pressure of $\mathrm{SO}_{2}$ was also investigated.

\section{Experimental}

\subsection{Aerosol generation}

The reaction system used to perform these experiments was discussed in detail previously (Trainer et al., 2004, 2006). The reactant gases were first combined in a mixing chamber where they were allowed to equilibrate for 12 hours to ensure homogeneity. The gas mixture was then flowed into a reaction chamber with a Mykrolis mass flow controller at a flow rate of 60 standard cubic centimeters per minute. As the reagent gases passed through the reaction chamber, they were exposed to either an electrical discharge (Tesla coil) to simulate lightning or a Hamamatsu broad-spectrum UV lamp with a wavelength range from $115-400 \mathrm{~nm}$ to simulate the UV region of the solar spectrum. Reactions within each chamber produced sulfur-containing aerosols. The gas mixtures were only exposed to the narrow line of spark discharge for a few seconds before being flowed through the reaction cell, similar to a lightning strike. The residence time for the gas inside the photochemical reaction chamber was 5 minutes. Note that particles in the real atmosphere would have far longer reaction times than those in the present work. The mechanical pump on our vacuum can theoretically pump down to 0.001 torr, which gave us a lower limit of $\mathrm{O}_{2}$ in our system of $10^{-6}$ PAL. This is within $\mathrm{O}_{2}$ levels that modelers predict should still produce $S_{8}$, especially with the addition of reducing gases (Zahnle et al., 2006).

\subsection{Particle characterization}

Aerosol composition as a function of reagent gas was measured with a quadrupole-based aerosol mass spectrometer (Q-AMS, Aerodyne Research, Billerica, MA) (Jayne et al., 2000; Canagaratna et al., 2007). The reacted particle/gas mixture flowed from the reaction chamber into the Q-AMS, where submicron particles were focused into a tight beam via an aerodynamic lens. The Q-AMS can be used in either the particle time-of-flight mode or in mass spectrum mode. The particle time-of-flight mode uses the terminal velocity of the particles in vacuum to determine their aerodynamic diameter, $d_{\text {va }}$ (DeCarlo et al., 2004), while in mass spectrum mode all particles are analyzed without size selection. The chemical composition of the particles was determined by flash vaporizing the particles on a heated tungsten surface at $600^{\circ} \mathrm{C}$ under high vacuum, followed by electron impact ionization $(70 \mathrm{eV})$ and mass analysis with a quadrupole mass spectrometer. With this technique, we were able to measure the mass spectra of the aerosol compounds in real time without the need for collection. The Q-AMS was well suited to these experiments because its inlet and differential pumping system concentrates the particles by a factor of $10^{7}$ relative to gaseous compounds, which thus minimizes gas 
phase interferences. In addition to composition and size information, the Q-AMS also supplies information on the mass concentration $\left(\mu \mathrm{g} \mathrm{m}^{-3}\right)$ of the particles sampled based on a calibration of the electron impact ionization signals (Jimenez et al., 2003).

For some experiments, a high-resolution time-of-flight aerosol mass spectrometer (HR-AMS) (DeCarlo et al., 2006) was also used in conjunction with the standard unit-mass resolution Q-AMS. The HR-AMS uses the same aerosol inlet, vaporization, and ionization system as the Q-AMS but with a time-of-flight mass spectrometer detection system in place of a quadrupole detector. Two analysis modes can be used for this system: a V-mode, with an effective ion path length of $1.3 \mathrm{~m}$; and a W-mode, with an effective ion path length of $2.9 \mathrm{~m}$. An order of magnitude of sensitivity is gained by operating in the $\mathrm{V}$-mode, but some resolution is lost (DeCarlo et al., 2006). In this study, we chose to operate the HR-AMS solely in the $\mathrm{W}$-mode for maximum peak resolution. While the Q-AMS has a resolving power of $m / \Delta m \sim 2 m$ at all mass-to-charge ratios $(\mathrm{m} / \mathrm{z})$, with $m$ being the nominal $m / z$ and $\Delta m$ being full width at half maximum, the HR-AMS in $\mathrm{W}$-mode has a maximum resolution of at least $\mathrm{m} /$ $\Delta m=4300$ at $200 \mathrm{~m} / \mathrm{z}$, which varies slightly over other $\mathrm{m} / \mathrm{z}$ (DeCarlo et al., 2006). This allows identification of peaks that have the same nominal mass but different chemical formulas. Thus, more positive identification of fragments arising from molecules with specific functional groups, such as organosulfur or oxygenated organic molecules, can be made.

\subsection{Gas mixtures}

Various amounts of trace gases were mixed along with a nitrogen $\left(\mathrm{N}_{2}\right)$ background overnight in a mixing chamber. $\mathrm{SO}_{2}$ (ultra high purity), $\mathrm{H}_{2}$ (ultra high purity), $\mathrm{CH}_{4}$ (research grade), $\mathrm{CO}_{2}$ (research grade), and $\mathrm{N}_{2}$ (ultra high purity) were purchased from Airgas Intermountain. A premixed standard gas of $2000 \pm 20$ ppmv $\mathrm{SO}_{2}$ in $\mathrm{N}_{2}$ was used as the starting gas for $\mathrm{SO}_{2}$ in some instances. Pure $\mathrm{SO}_{2}$ was diluted with $\mathrm{N}_{2}$ for higher mixing ratio experiments with UV photolysis. The aerosol mass spectrometer (AMS) spectra of each gas mixture was obtained before initiating reaction and then subtracted from the aerosol spectra to reduce gas interference in our results.

The HR-AMS spectrum of the background gases was used to verify the $\mathrm{O}_{2}$ upper limit. $\mathrm{No} \mathrm{O}_{2}$ was detected in the mass spectrum of the background gas mixture. At our running conditions, the HR-AMS could detect $\mathrm{O}_{2}$ gas levels of 200 ppmv and above. Thus, an upper limit of $\mathrm{O}_{2}$ in the gas mixture less than $10^{-3}$ PAL was confirmed with the HRAMS. Combining this calculation with the pumping capability of our vacuum system gives a possible range of $10^{-6}$ to $10^{-3} \mathrm{PAL} \mathrm{O}_{2}$ in the reaction chamber.

2.3.1. Electrical discharge. To simulate a volcanic plume, $20 \pm 0.2 \mathrm{ppmv} \mathrm{SO}_{2}$ with, and without, $0.1 \%$ $\left(1000 \pm 20\right.$ ppmv) $\mathrm{CO}_{2}$ and with varying amounts of $\mathrm{H}_{2}$ were mixed together. $\mathrm{CO}_{2}$ was used as both an additional oxidant and a potential carbon source, while $\mathrm{H}_{2}$ was used as an additional reductant. The overall amount of $\mathrm{H}_{2}$ was varied to change the average oxidation state of the gas mixtures. $\mathrm{CO}_{2}$ was used in half the experiments. To simplify the aerosol spectra and their interpretation, we chose $\mathrm{H}_{2}$ instead of $\mathrm{CH}_{4}$ as a reductant for the electrical discharge experiments even though models have shown that both could affect $\mathrm{SO}_{2}$ chemistry in similar ways (Zahnle et al., 2006) and both could have been present in elevated amounts in the atmosphere of early Earth (Pavlov et al., 2000; Tian et al., 2005).

2.3.2. Photolysis. We used gas mixtures with varying amounts of $\mathrm{SO}_{2}$ and $\mathrm{CH}_{4}$ in a $\mathrm{N}_{2}$ background to simulate the photochemical reactions that potentially occurred in the atmosphere of Archean Earth. We varied the partial pressure of $\mathrm{SO}_{2}$ from $2( \pm 0.2)$ to $20,000( \pm 20)$ ppmv in our experiments to probe the effect of the $\mathrm{SO}_{2}$ mixing ratio on aerosol formation. $\mathrm{SO}_{2}$ amounts from 2 to 2000 ppmv are not unreasonable for volcanic clouds in early Earth's atmosphere following a volcanic eruption. For some experiments, we added $1000 \pm 20$ ppmv $\mathrm{CH}_{4}$ to our mixtures, a reasonable amount of $\mathrm{CH}_{4}$ for the late Archean (Haqq-Misra et al., 2008). While $\mathrm{H}_{2}$ was added to several gas mixtures, no effect was observed, likely because $\mathrm{H}_{2}$ does not photolyze at the wavelengths used in our experiment. Thus, $\mathrm{CH}_{4}$ was used as the main reducing gas in the photolysis studies.

\section{Results}

\subsection{Electrical discharge}

Figure 1a shows the aerosol mass spectra of $20 \mathrm{ppmv} \mathrm{SO}_{2}$ exposed to an electrical discharge. At $20 \mathrm{ppmv} \mathrm{SO}_{2}$, the majority of the aerosol formed was $\mathrm{H}_{2} \mathrm{SO}_{4}$, which resulted from reaction of $\mathrm{SO}_{2}$ and hydroxyl $(\mathrm{OH})$ radicals formed from trace $\mathrm{H}_{2} \mathrm{O}$. Although the vacuum reaction chamber was evacuated to under a torr and kept at this level, the trace amounts of water left in the vacuum chamber or brought along with the gases heavily influenced the resulting aerosol composition after the gases were exposed to electrical discharge. Farquhar et al. (2001) also saw $\mathrm{H}_{2} \mathrm{SO}_{4}$ in their experiments without added $\mathrm{H}_{2} \mathrm{O}$. Increasing $\mathrm{H}_{2}$ from 0 to $10 \%$ of the total gas mixture slowly increased the relative ratio of $\mathrm{S}_{8} /$ $\mathrm{H}_{2} \mathrm{SO}_{4}$ in the aerosol formed. As an example, Fig. 1b shows the mass spectrum with $5 \% \mathrm{H}_{2}$. Here, the mass signature for elemental sulfur is clearly observed. The Q-AMS can be used to quantify the fraction of $S_{8}$ formed under varying conditions. Figure 2 shows the relative amounts of characteristic $\mathrm{H}_{2} \mathrm{SO}_{4}$ and $\mathrm{S}_{8}$ peaks from the electrical discharge of $20 \mathrm{ppmv}$ $\mathrm{SO}_{2}$ as a function of $\mathrm{H}_{2}$ (not including overlapping peaks). It can be seen that above $4 \% \mathrm{H}_{2}, \mathrm{~S}_{8}$ is the dominant $\mathrm{S}$ aerosol formed. The experiments were repeated with the addition of $1000 \pm 20$ ppmv (0.1\%) $\mathrm{CO}_{2}$ added to the $\mathrm{SO}_{2} / \mathrm{H}_{2} / \mathrm{N}_{2}$ mixture. Figure 2 shows that again for this mixture the addition of $\mathrm{H}_{2}$ favors the formation of $\mathrm{S}_{8}$ over $\mathrm{H}_{2} \mathrm{SO}_{4}$. However, with the additional $\mathrm{CO}_{2}$ oxidant added, more $\mathrm{H}_{2}$ is needed to switch the aerosol formed from mainly $\mathrm{H}_{2} \mathrm{SO}_{4}$ to mainly $\mathrm{S}_{8}$.

\subsection{UV experiments}

3.2.1. The effect of the $\mathrm{SO}_{2}$ mixing ratio on aerosol chemistry. For the UV experiments, gas mixtures containing varying mixing ratios of $\mathrm{SO}_{2}$ were exposed to a broadspectrum UV light source with wavelengths that ranged from 115 to $400 \mathrm{~nm}$. Varying amounts of $\mathrm{CH}_{4}$ and $\mathrm{H}_{2}$ were added to the gas mixtures. The empty reaction chamber was exposed to UV light for 15 minutes while under vacuum prior to each experiment to photolyze $\mathrm{H}_{2} \mathrm{O}$ contamination on 


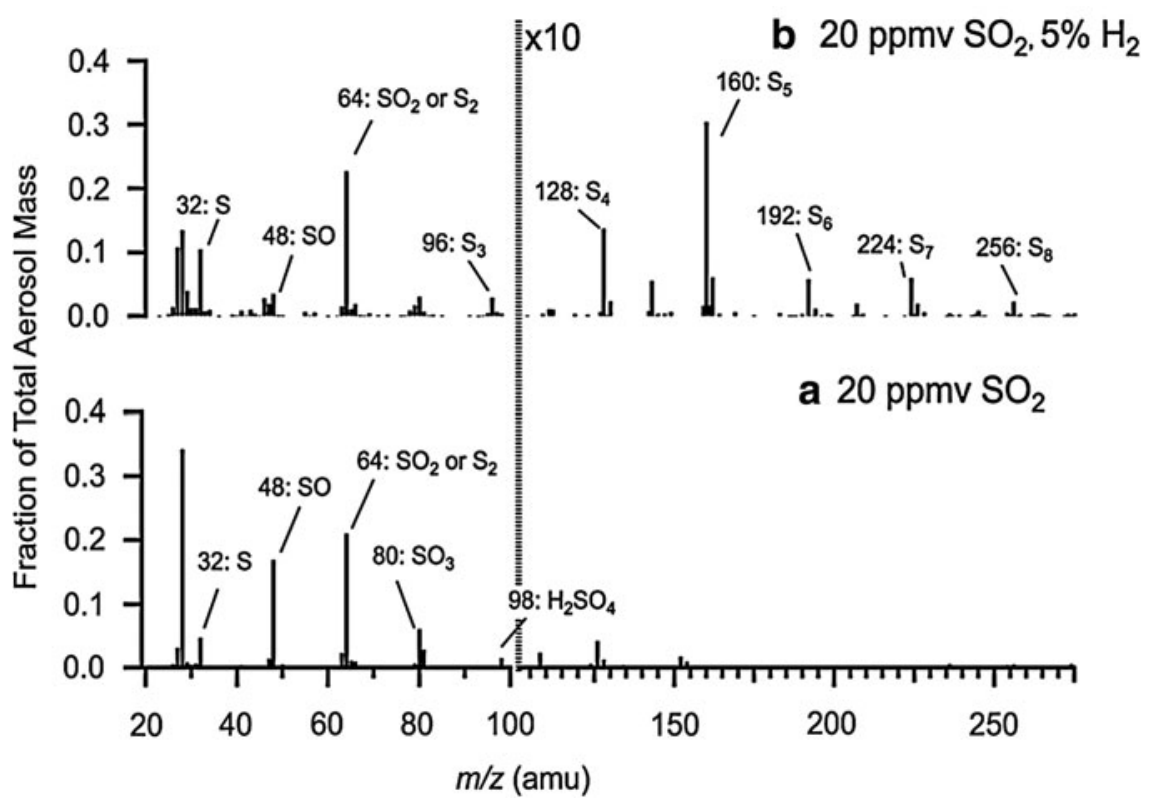

FIG. 1. Q-AMS spectra of particles formed from the electrical discharge of 20 ppmv $\mathrm{SO}_{2}$ in $\mathrm{N}_{2}$, without (a) and with (b) 50,000 ppmv (5\%) $\mathrm{H}_{2}$. Plotted is fraction of total aerosol mass versus $\mathrm{m} / \mathrm{z}$ (amu). Likely peak identifications have been made. Spectra to the right of the dashed line have been multiplied by 10 for ease of viewing. Small signals not from $\mathrm{S}_{8}$ or $\mathrm{H}_{2} \mathrm{SO}_{4}$ aerosols (unlabeled peaks) are around the noise level of the instrument and could be from trace contamination from the gas or flow system. the walls of the reaction vessel. The reaction cell was also cooled both before and during reaction to $273 \mathrm{~K}$ with a methanol cooler in an attempt to reduce $\mathrm{H}_{2} \mathrm{O}$ contamination. Although we achieved some reduction in $\mathrm{H}_{2} \mathrm{O}$, not all the $\mathrm{H}_{2} \mathrm{O}$ contamination was removed.

The mixing ratio of $\mathrm{SO}_{2}$ was varied to investigate the effect of initial partial pressure on the aerosol chemistry. With 2, 20, 200 , and 2000 ppmv $\mathrm{SO}_{2}$ in $\mathrm{N}_{2}$, only the $\mathrm{H}_{2} \mathrm{SO}_{4}$ signal was observed. Figure 3 a shows a representative spectrum using 2000 ppmv $\mathrm{SO}_{2}$. When $\mathrm{SO}_{2}$ was further increased to $2 \%$ of the total gas mixture, a complete spectral signature for elemental sulfur through $\mathrm{S}_{8}$ was observed in addition to $\mathrm{H}_{2} \mathrm{SO}_{4}$ (Fig. 3b). Note that Farquhar et al. (2001) also used $2 \% \mathrm{SO}_{2}$ in $\mathrm{N}_{2}$ and observed the formation of both $\mathrm{S}_{8}$ and $\mathrm{H}_{2} \mathrm{SO}_{4}$ aerosols. When $\mathrm{SO}_{2}$ was increased to $4 \%$ of the total gas mixture, a further increase in the elemental sulfur signature was observed (not shown). Two percent $\mathrm{SO}_{2}$ photolyzed at room temperature rather than $273 \mathrm{~K}$ did not form $\mathrm{S}_{8}$, possibly indicating the importance of the increased $\mathrm{H}_{2} \mathrm{O}$ in the cell at room temperature.

3.2.2. The effect of reducing gases on $\mathrm{SO}_{2}$ aerosol chemistry. In addition to exploring the effects of the $\mathrm{SO}_{2}$ mixing ratio on UV photolysis aerosol chemistry, we also probed the effect of adding reducing gases. Initially $1 \% \mathrm{H}_{2}$ was added to a 2000 ppmv $\mathrm{SO}_{2}$ gas mixture, but no change was observed in the mass spectrum. Although $\mathrm{H}_{2}$ does not photolyze at any of the wavelengths emitted by the UV lamp, it is possible that reactions such as $\mathrm{H}_{2}+\mathrm{O} \rightarrow \mathrm{OH}+\mathrm{H}$ or $\mathrm{H}_{2}+\mathrm{OH} \rightarrow \mathrm{H}_{2} \mathrm{O}+\mathrm{H}$ could have occurred; thus $\mathrm{H}_{2}$ could have affected the S-aerosol chemistry (Moses et al., 2000). However, these reactions are slow, and our experimental results do not reflect them occurring. Under our experimental conditions, it is likely that the much faster reaction of $\mathrm{SO}_{2}+$ $\mathrm{OH}+\mathrm{M} \rightarrow \mathrm{HSO}_{3}$ outcompetes the reaction of $\mathrm{OH}$ with $\mathrm{H}_{2}$.

In contrast to adding $\mathrm{H}_{2}$ to the initial gas mixture, the combination of 1000 ppmv $\mathrm{CH}_{4}$ with 2000 ppmv $\mathrm{SO}_{2}$ results in a strong $\mathrm{S}_{8}$ signal in addition to the $\mathrm{H}_{2} \mathrm{SO}_{4}$ signal (Fig. 3c), with mass signal in the aerosol mass spectrum for $S_{1}-S_{8}$.
Similar experiments were performed on $2 \%$ and $4 \% \mathrm{SO}_{2}$ gas mixtures, both with 1000 ppmv $\mathrm{CH}_{4}$. In these cases, adding $\mathrm{CH}_{4}$ to the initial gas mixture increased the amount of $\mathrm{S}_{8}$ compared to gas mixtures with the same mixing ratio of $\mathrm{SO}_{2}$ but without $\mathrm{CH}_{4}$. Figure 4 shows a summary of the fraction of $\mathrm{S}_{8}$ aerosol found as a function of $\mathrm{SO}_{2}$ pressure, both with and without added $\mathrm{CH}_{4}$. It can be seen that both increasing the initial $\mathrm{SO}_{2}$ mixing ratio and adding $\mathrm{CH}_{4}$ increase the $\mathrm{S}_{8}$ fraction.

3.2.3. Formation of organosulfur from $\mathrm{CH}_{4} / \mathrm{SO}_{2}$ photolysis. While Fig. $3 \mathrm{c}$ shows $\mathrm{CH}_{4}$ addition helps the formation of $\mathrm{S}_{8}$, other S-bearing peaks were observed in the AMS spectrum, especially at lower levels of $\mathrm{SO}_{2}$. Figure 5 shows the resulting spectrum from the photolysis of $2 \mathrm{ppmv} \mathrm{SO}_{2}$ and $1000 \mathrm{ppmv} \mathrm{CH}_{4}$. Although the prevalent mass peaks for the 2 ppmv $\mathrm{SO}_{2}$ mixture followed $\mathrm{a}_{2} \mathrm{SO}_{4}$ and a separate organic ion series pattern, organosulfur species have been

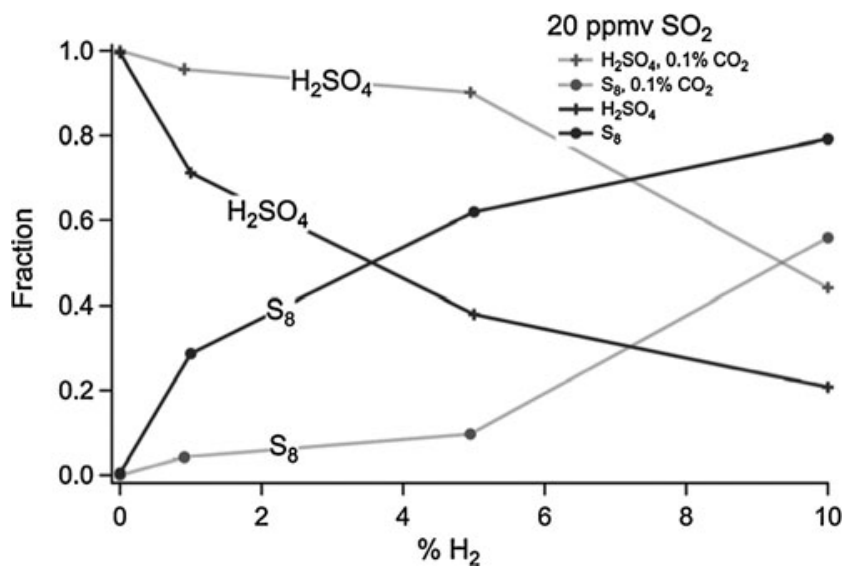

FIG. 2. Relative fraction of total S-bearing aerosol signal of characteristic $\mathrm{H}_{2} \mathrm{SO}_{4}$ peaks (crosses) and $\mathrm{S}_{8}$ peaks (circles) versus percent $\mathrm{H}_{2}$ calculated from Q-AMS data. Experiments with $\mathrm{CO}_{2}$ are shown with a dashed line. Overlapping mass peaks for $\mathrm{H}_{2} \mathrm{SO}_{4}$ and $\mathrm{S}_{8}(\mathrm{~m} / \mathrm{z} 32$ and 64) have not been included in these calculations. 


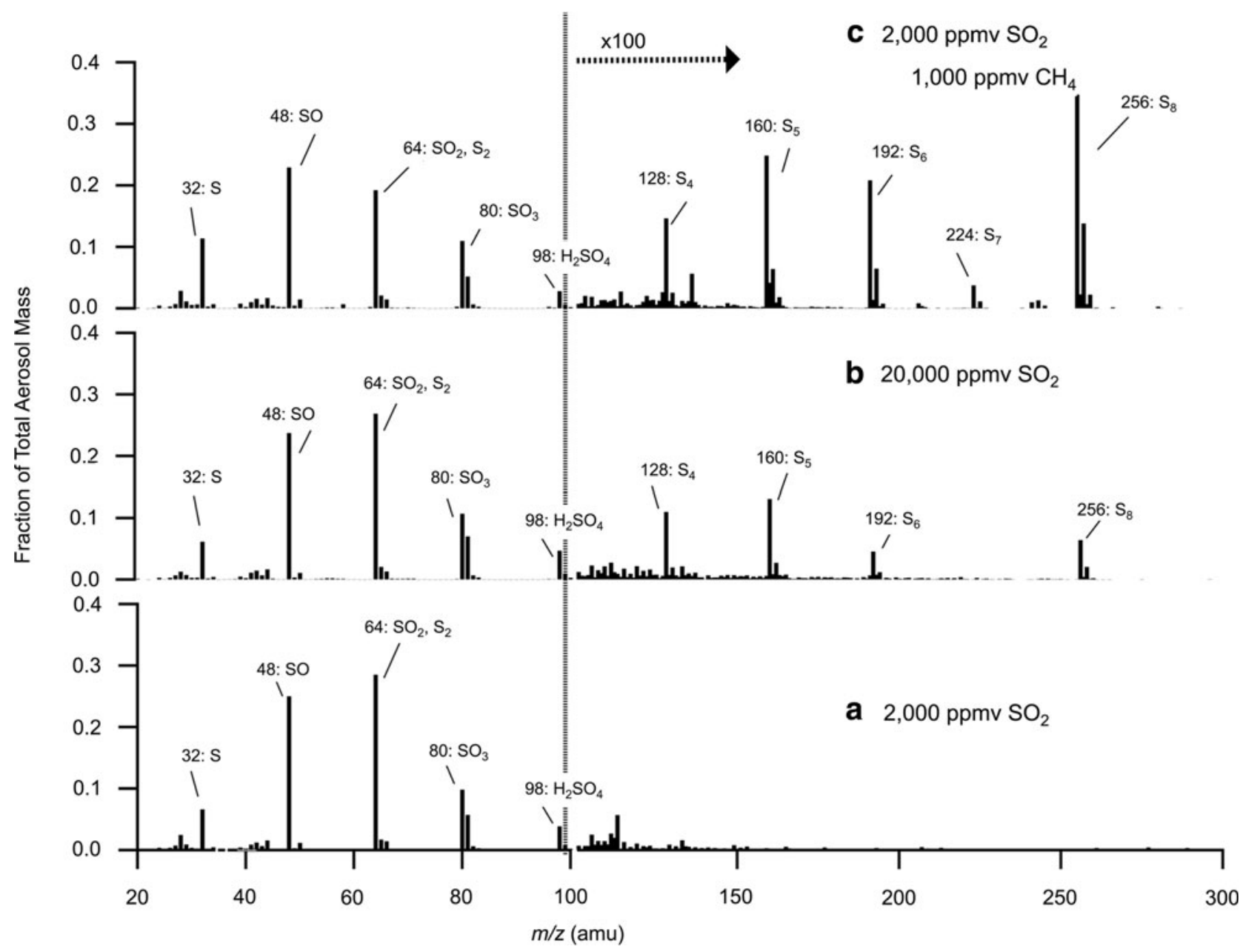

FIG. 3. Q-AMS spectra of particles formed from the photolysis of $2000 \mathrm{ppmv}(0.2 \%) \mathrm{SO}_{2}$ in $\mathrm{N}_{2}$ (a); 20,000 ppmv SO (b); and 2000 ppmv SO 2 with 1000 ppmv $\mathrm{CH}_{4}$ (c). Plotted is fraction of total aerosol mass versus $\mathrm{m} / \mathrm{z}$ (amu). Likely peak identification has been made. Peaks to the right of the dashed line have been multiplied by 100 for ease of viewing. Small signals not from $\mathrm{S}_{8}$ or $\mathrm{H}_{2} \mathrm{SO}_{4}$ aerosols (unlabeled peaks) for mass spectra without $\mathrm{CH}_{4}$ are around the noise level of the instrument and could be from trace contamination from the gas or flow system.

shown to fragment in the HR-AMS to predominately hydrocarbon and $\mathrm{H}_{2} \mathrm{SO}_{4}$ peaks. $\mathrm{No} \mathrm{S}_{8}$ was observed at this low level of $\mathrm{SO}_{2}$. However, some amount of organosulfur was observed in the HR-AMS data. Specifically, $\mathrm{CH}_{3} \mathrm{SO}_{2}^{+}$(HRAMS spectra shown in Fig. 5 inset), $\mathrm{CH}_{3} \mathrm{SO}^{+}$, and $\mathrm{CH}_{3} \mathrm{~S}^{+}$ were observed. We also observed $\mathrm{HS}^{+}$and $\mathrm{H}_{2} \mathrm{~S}^{+}$peaks. The $\mathrm{CH}_{3} \mathrm{SO}_{2}^{+}$peak is prominent in the AMS spectrum of methyl sulfonic acid (MSA, $\mathrm{CH}_{3} \mathrm{SO}_{3} \mathrm{H}$ ), and the fragmentation of MSA in the AMS is well characterized (Zorn et al., 2008). Using MSA as a model for organosulfur species, one can determine a $\mathrm{CH}_{3} \mathrm{SO}_{2}^{+} / \mathrm{H}_{2} \mathrm{SO}_{4}$ ratio of 0.25 and apply this ratio to our data (Zorn et al., 2008). This allows one to roughly quantify the amount of sulfate signal due to an organosulfur compound such as MSA as opposed to that from inorganic sulfate. This is illustrated in Fig. 5a. From this calculation, it can be seen that approximately $16 \%$ of the sulfate signal could be due to MSA fragmentation for $2 \mathrm{ppmv}$ $\mathrm{SO}_{2}$ with 1000 ppmv $\mathrm{CH}_{4}$.

The spectrum was also compared to a standard organosulfate spectrum (trihydroxy sulfate ester, $\mathrm{C}_{5} \mathrm{H}_{12} \mathrm{O}_{7} \mathrm{~S}$ ) by normalizing the organosulfate spectrum's $\mathrm{CH}_{3} \mathrm{SO}_{2}^{+}$peak to that in the spectrum of $2 \mathrm{ppmv} \mathrm{SO}_{2}$ with 1000 ppmv $\mathrm{CH}_{4}$
(Farmer et al., 2010). When comparing the resulting spectra, the normalized standard organosulfate spectrum's sulfate signal is approximately 7 times larger than that of the spectrum from these experiments. Thus, $14 \%$ of our $\mathrm{CH}_{3} \mathrm{SO}_{2}^{+}$peak could be due to organosulfate, with the rest of the signal from other less-oxidized organosulfur species such as MSA.

Although the spectrum for the $20 \mathrm{ppmv} \mathrm{SO}_{2}$ mixture looked very similar to that of the 2 ppmv $\mathrm{SO}_{2}$ mixture, there was an approximate factor of 2 reduction in the relative prominence of organosulfur peaks as compared to $\mathrm{H}_{2} \mathrm{SO}_{4}$ peaks with increased $\mathrm{SO}_{2}$.

Note that no $\mathrm{S}_{8}$ was observed from the photolysis of 1000 ppmv $\mathrm{CH}_{4}$ with 20 ppmv and below $\mathrm{SO}_{2}$. All the UV experiments and results have been summarized in Table 1.

\section{Discussion}

Our studies allowed real-time analysis of nonrefractory aerosol compound produced in the flow system simulating the aerosol potentially formed from volcanic emissions in an early Earth atmosphere. In these experiments, trace amounts 


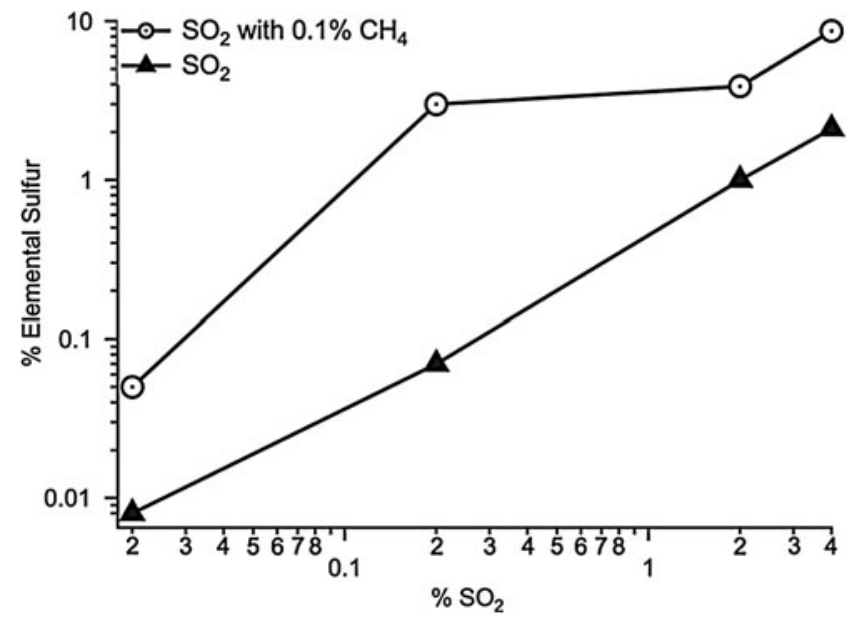

FIG. 4. Percent of S-bearing aerosol mass from $\mathrm{S}_{8}$ as a function of the pressure of $\mathrm{SO}_{2}$ calculated from Q-AMS data. Experiments are shown with (circles) and without (triangles) 1000 ppmv $\mathrm{CH}_{4}$. Overlapping mass peaks for $\mathrm{H}_{2} \mathrm{SO}_{4}$ and $\mathrm{S}_{8}$ $(\mathrm{m} / \mathrm{z} 32$ and 64) have not been included in these calculations.

of $\mathrm{H}_{2} \mathrm{O}$ in the vacuum reaction cell were enough to oxidize most of the sulfur to $\mathrm{H}_{2} \mathrm{SO}_{4}$. We cooled our reaction vessel to $273 \mathrm{~K}$. This gives us a theoretical water vapor concentration of $0.7 \%$, or $7000 \mathrm{ppmv}$ within the reaction cell as an upper limit. The HR-AMS background gas spectrum further limits the $\mathrm{H}_{2} \mathrm{O}$ contamination to $1000 \mathrm{ppmv}$. For lower altitudes and within volcanic plumes this would be relevant, as water would be present in at least trace amounts at low altitudes and would also be emitted along with $\mathrm{SO}_{2}$ from volcanoes (Pavlov et al., 2000; Textor et al., 2003). At $2 \% \mathrm{SO}_{2}$, photolysis in a room-temperature reaction cell did not yield $S_{8}$, illustrating that the water vapor in the reaction cell was affecting the aerosol chemistry.

In our discharge experiments, we studied a simple system in which we increased the reducing gases, in this case $\mathrm{H}_{2}$, to avoid the complication of organic chemistry from $\mathrm{CH}_{4}$. The addition of $\mathrm{H}_{2}$ to the gas mixture caused elemental sulfur aerosol to form in addition to $\mathrm{H}_{2} \mathrm{SO}_{4}$. Increasing the amount of $\mathrm{H}_{2}$ increased the $\mathrm{S}_{8} / \mathrm{H}_{2} \mathrm{SO}_{4}$ ratio. Zahnle et al. (2006) found that increasing the reduced gases in his 1-D model of early Earth's atmosphere increased the $\mathrm{S}_{8} / \mathrm{H}_{2} \mathrm{SO}_{4}$ ratio, and our results appear to support this finding. One explanation for this is that $\mathrm{H}$ formed from the electrical dissociation of $\mathrm{H}_{2}$ titrated the $\mathrm{OH}$ formed from $\mathrm{H}_{2} \mathrm{O} . \mathrm{H}_{2}$ could also titrate the $\mathrm{O}$ atoms from $\mathrm{SO}_{2}$ photolysis, facilitating the formation of more reduced sulfur compounds. Alternatively, intermediate $\mathrm{HS}_{n}$ compounds may increase $\mathrm{S}$ chain formation (Kasting et al., 1989). Excess $\mathrm{H}_{2}$ would contribute to the formation of $\mathrm{HS}_{n}$ compounds and partially explain our results. The same effect, albeit dampened, is observed when $\mathrm{CO}_{2}$ is added to the gas mixture. The increased $\mathrm{O}$ from $\mathrm{CO}_{2}$ photolysis most likely explains the lower amounts of $\mathrm{S}_{8}$ formed with $\mathrm{CO}_{2}$ than without for the same level of $\mathrm{H}_{2}$. Our experiments do not allow us to determine the isotopic fractionation of $\mathrm{SO}_{2}$, and in fact electrical discharge may not even produce S-MIF.

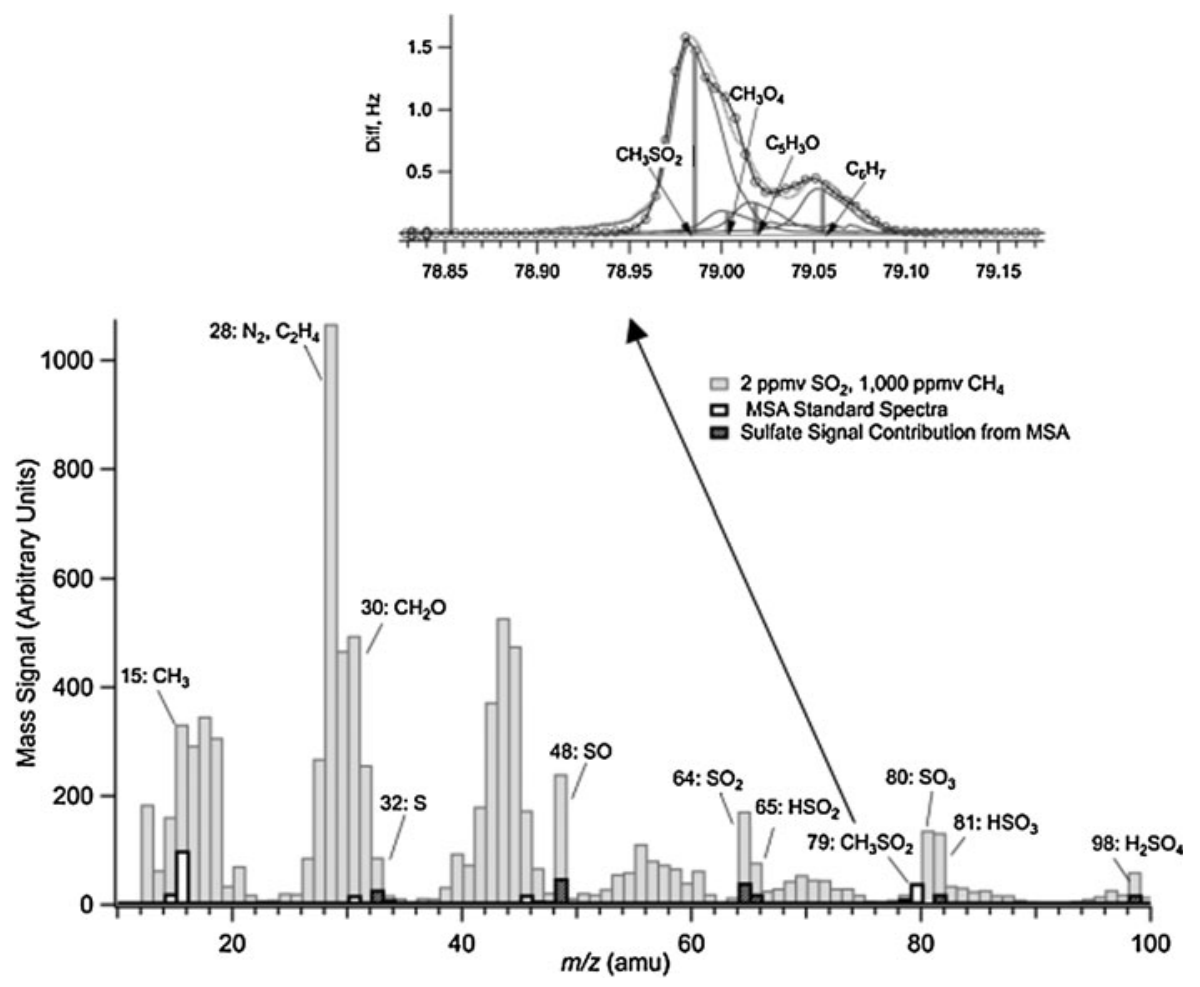

FIG. 5. AMS spectrum of particles formed from the photolysis of $2 \mathrm{ppmv} \mathrm{SO}_{2}$ with 1000 ppmv $\mathrm{CH}_{4}$ in $\mathrm{N}_{2}$ (gray boxes) with the standard AMS spectrum of MSA (black lines). The two spectra are normalized so that the intensity of $\mathrm{CH}_{3} \mathrm{SO}_{2}^{+} /(\mathrm{m} / z$ 79) is equal in each spectrum. Patterned boxes are the sulfate contribution from MSA. Approximately $16 \%$ of the sulfate signal in the 2 ppmv SO 1000 ppmv $\mathrm{CH}_{4}$ spectra could be from MSA. The expanded high-resolution peak from the organosulfur peak $\mathrm{CH}_{3} \mathrm{SO}_{2}^{+}$is shown in the inset. 
Table 1. Summary of $\mathrm{SO}_{2}$ UV Photolysis Experiments

\begin{tabular}{|c|c|c|c|c|c|}
\hline $\begin{array}{l}\text { Experimental } \\
\mathrm{SO}_{2}(\text { ppmv })\end{array}$ & Reducing gas? & $S_{8} ?$ & Organosulfur? & $\begin{array}{c}\mathrm{H}_{2} \mathrm{O} \text { level } \\
\text { in experiment } \\
\text { (upper limit) }\end{array}$ & $\begin{array}{c}\mathrm{O}_{2} \text { level in } \\
\text { experiment, } P A L \\
\text { (upper limit) }\end{array}$ \\
\hline $2 \pm 0.02$ & $1,000 \pm 20 \mathrm{ppmv}^{\mathrm{CH}} \mathrm{H}_{4}$ & No & $\begin{array}{l}\text { Yes, present } \\
\text { and studied }\end{array}$ & Unknown & $10^{-3}$ \\
\hline $20 \pm 0.2$ & 1,000 ppmv $\mathrm{CH}_{4}$ & No & $\begin{array}{l}\text { Yes, present } \\
\text { and studied }\end{array}$ & 7,000 ppmv & $10^{-3}$ \\
\hline $200 \pm 2$ & No & No & Not studied & 7,000 ppmv & $10^{-3}$ \\
\hline $200 \pm 2$ & 1,000 ppmv $\mathrm{CH}_{4}$ & No & Not studied & 7,000 ppmv & $10^{-3}$ \\
\hline $2,000 \pm 20$ & No & No & Not studied & 7,000 ppmv & $10^{-3}$ \\
\hline $2,000 \pm 20$ & $10,000 \pm 20$ ppmv $\mathrm{H}_{2}$ & No & Not studied & 7,000 ppmv & $10^{-3}$ \\
\hline $2,000 \pm 20$ & $1,000 \mathrm{ppmv} \mathrm{CH}_{4}$ & Yes & Not studied & 7,000 ppmv & $10^{-3}$ \\
\hline $20,000 \pm 20$ & No & Yes & Not studied & 7,000 ppmv & $10^{-3}$ \\
\hline $20,000 \pm 20$ & 1,000 ppmv $\mathrm{CH}_{4}$ & Yes & Not studied & 7,000 ppmv & $10^{-3}$ \\
\hline $40,000 \pm 20$ & No & Yes & Not studied & 7,000 ppmv & $10^{-3}$ \\
\hline $40,000 \pm 20$ & 1,000 ppmv $\mathrm{CH}_{4}$ & Yes & Not studied & 7,000 ppmv & $10^{-3}$ \\
\hline $\begin{array}{l}\text { Amount present } \\
\text { on early Earth }\end{array}$ & $\begin{array}{l}\mathrm{SO}_{2}: 10 \mathrm{ppbv}^{\mathrm{a}} \\
\quad \text { (global lower limit) }\end{array}$ & $\begin{array}{l}\mathbf{H}_{\mathbf{2}} \mathbf{O} \text { : Unknown, } \\
\text { likely }>7,000 \mathrm{ppmv}^{\mathrm{b}} \\
\text { at low altitudes }\end{array}$ & $\begin{array}{l}\mathrm{O}_{2}: \text { modeled to } \\
\quad \text { be from } 10^{-5} \mathrm{ppmv}^{\mathrm{c}} \\
\text { to } 10^{-13} \mathrm{ppmv}^{\mathrm{b}}\end{array}$ & 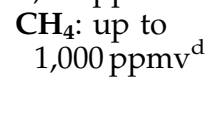 & \\
\hline
\end{tabular}

${ }^{\text {a } K a s t i n g ~ e t ~ a l . ~(1989) . ~}$

${ }^{\mathrm{b}}$ Pavlov and Kasting (2002).

${ }^{c}$ Farquhar et al. (2000).

${ }^{\mathrm{d}}$ Haqq-Misra et al. (2008).

We observe the same effect in our photolysis experiments when we add $\mathrm{CH}_{4}$ to the initial gas mixtures. With the addition of 1000 ppmv $\mathrm{CH}_{4}, \mathrm{~S}_{8}$ is formed at 2000 ppmv initial $\mathrm{SO}_{2}$ mixing ratio. Adding $1000 \mathrm{ppmv} \mathrm{CH}_{4}$ to $2 \%$ and $4 \% \mathrm{SO}_{2}$ gas mixtures increases $\mathrm{S}_{8}$ formation by a factor of 2 or more. We infer from these experiments that the relative oxidative capacity, or amount of reducing gases relative to oxidizing gases, in a volcanic plume and the ambient atmosphere can greatly change the chemical composition of the aerosols formed in and around a volcanic cloud.

The experimental paper by Farquhar et al. (2001) showed the formation of $\mathrm{S}_{8}$ and $\mathrm{H}_{2} \mathrm{SO}_{4}$ aerosols with $\mathrm{UV}$ photolysis but with unrealistically high concentrations of $\mathrm{SO}_{2}$ and noncontinuum UV light sources. In our experiments, we exposed $\mathrm{SO}_{2}, \mathrm{CH}_{4}$, and $\mathrm{CO}_{2}$ to a broad-spectrum UV light with a peak in emission at $\sim 145 \mathrm{~nm}$, under the $220 \mathrm{~nm}$ cutoff determined by Farquhar et al. (2001) to be the wavelength of UV for S-MIF formation. We probed the effect that the initial $\mathrm{SO}_{2}$ pressure had on the resulting sulfur aerosol chemistry. We observed $\mathrm{S}_{8}$ formation with $2 \% \mathrm{SO}_{2}$ but only $\mathrm{H}_{2} \mathrm{SO}_{4}$ aerosol formation with 200 ppmv and lower $\mathrm{SO}_{2}$. While the lack of $\mathrm{S}_{8}$ production at lower $\mathrm{SO}_{2}$ values may reflect the importance of the $\mathrm{SO}_{2}$ self-reaction, it may partially also reflect the relative abundance of $\mathrm{SO}_{2}$ and water vapor in the system. Models predict efficient $\mathrm{S}_{8}$ formation at much lower levels of $\mathrm{SO}_{2}$ than we observe experimentally, at levels of 10 ppbv (Kasting et al., 1989) in models versus 2000 ppmv or higher in our experiments. Our experimental photochemical reaction time of 5 minutes is significantly lower than reaction times in the atmosphere, and this could also have affected our results. The rate constants are not known well enough to determine how much of an effect reaction time would have on $S_{8}$ production (Kasting et al., 1989). Although our theoretical lower limit for $\mathrm{O}_{2}$ in our vacuum chamber was on the order of $10^{-6}$ PAL, we were only able to experimentally determine a $10^{-3} \mathrm{PAL} \mathrm{O}_{2}$ upper limit after our experiments began, giving us a wide range of possible $\mathrm{O}_{2}$ levels, which could have also affected our results. Ono et al. (2003) also predicted a $\mathrm{SO}_{2}$ pressure dependence on the $\mathrm{S}_{8} /$ $\mathrm{H}_{2} \mathrm{SO}_{4}$ ratio, which they attributed to the increased $\mathrm{S}$ atom requirement to form $\mathrm{S}_{8}$ over $\mathrm{H}_{2} \mathrm{SO}_{4}$. In our system, $\mathrm{S}++\mathrm{S}$ must combine to form $S_{2}, S_{2}+S_{2}$ to form $S_{4}$, and so on. These reactions are also sensitive to total pressure, as the combination reactions of $S$ atoms to form $S$ chains are three-body reactions (Kasting et al., 1989). However, the possible pressure dependence of sulfur aerosol formation was not probed

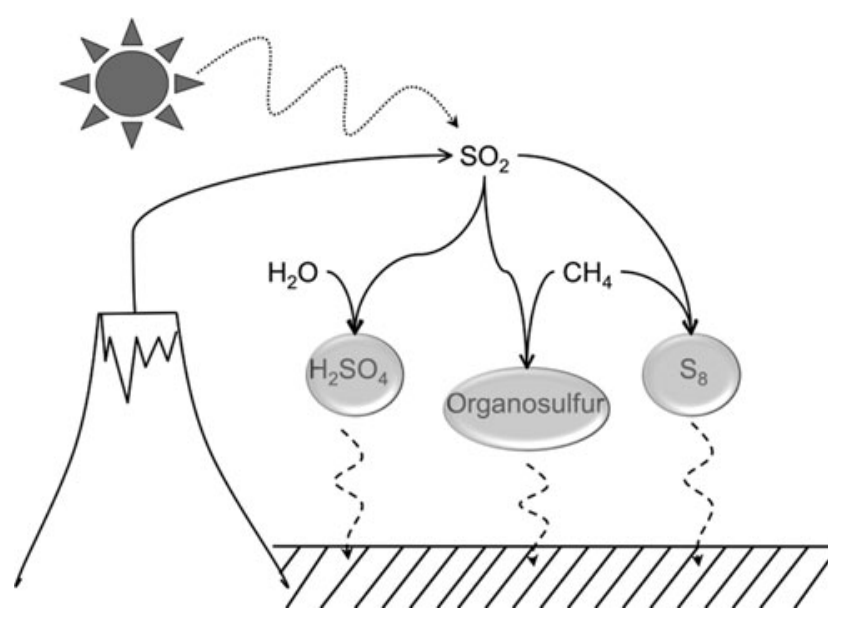

FIG. 6. A conceptual model of the formation and preservation of S-MIF in early Earth's atmosphere under different atmospheric conditions. More $\mathrm{H}_{2} \mathrm{O}$ increases the formation of $\mathrm{H}_{2} \mathrm{SO}_{4}$, while moderate amounts of $\mathrm{CH}_{4}$ form more organosulfur and $\mathrm{S}_{8}$ aerosols. A high $\mathrm{CH}_{4} / \mathrm{SO}_{2}$ ratio increases the amount of organosulfur formed. Increasing the mixing ratio of $\mathrm{SO}_{2}$ increases the amount of $\mathrm{S}_{8}$ formed, as does adding $\mathrm{CH}_{4}$, once the $\mathrm{SO}_{2}$ pressure is at a certain threshold. 
in the present work, as all our experiments were conducted at 600 torr.

Models have suggested that $\mathrm{O}_{2}$ levels of $10^{-5}$ PAL or greater will shut off S-MIF formation (Pavlov and Kasting, 2002). Below this level, $\mathrm{O}_{2}$ would not be well mixed (Pavlov and Kasting, 2002). We calculate that our mixing chamber has an upper limit of $\mathrm{O}_{2}$ at $10^{-3}$ PAL. We still observe the formation of elemental sulfur aerosols under certain experimental conditions with both electrical discharge and photolysis as the driving force for these reactions. One reason for this could be that our initial $\mathrm{SO}_{2}$ levels are significantly higher than the atmospheric levels in the models used to predict $\mathrm{O}_{2}$ levels. For example, we observed the formation of $\mathrm{S}_{8}$ when $2000 \mathrm{ppmv}$ $\mathrm{SO}_{2}$ was used for the photolysis experiments, a much higher amount of $\mathrm{SO}_{2}$ than the $10 \mathrm{ppbv} \mathrm{SO}_{2}$ that is predicted to have been present in early Earth's atmosphere. In addition, we added reducing gases such as $\mathrm{H}_{2}$ or $\mathrm{CH}_{4}$.

Organosulfur formed from the photolysis of the biologically produced gases $\mathrm{CS}_{2}$ and OCS have been found to contain S-MIF (Lyons, 2009), and our research points to an additional abiological source of organosulfur aerosols in early Earth's atmosphere. Ueno et al. (2009) attributed the buildup of OCS in the atmosphere to the reaction $\mathrm{CO}+\mathrm{S}_{n}+\mathrm{M} \rightarrow$ OCS. In this research, we have found that it can be difficult to build up significant amounts of $S_{n}$. However, we found organosulfur to be present in aerosols formed from the photolysis of moderate amounts of $\mathrm{SO}_{2}$ and $\mathrm{CH}_{4}$. Although the signal from organosulfur peaks was relatively small compared to the sulfate signal in our spectra, organosulfur species have been shown to fragment in the AMS to peaks typically associated separately with organics and $\mathrm{H}_{2} \mathrm{SO}_{4}$. Using MSA as a model for organosulfur aerosols, we find that at least $16 \%$ of our sulfate aerosol signal could come from organosulfur for a gas mixture of $2 \mathrm{ppmv} \mathrm{SO}_{2}$ and 1000 ppmv $\mathrm{CH}_{4}$. Organosulfate species fractionate even more strongly into sulfate and organic peaks in the AMS, with a greater sulfate/organosulfur ratio than we observe in our laboratory spectrum. By comparing a standard organosulfate spectrum to our spectrum, we calculated an upper limit of $14 \%$ of our organosulfur signal could be from organosulfate. Additionally, we find evidence of $\mathrm{CH}_{3} \mathrm{~S}^{+}$peaks in our HR-AMS spectrum, which indicates that some of our organosulfur signal must come from species with a $\mathrm{C}-\mathrm{S}$ bond, such as sulfonic acids or thiols (H-S-R). Organosulfate has only $\mathrm{C}-\mathrm{O}-\mathrm{S}$ bonds. Observing $\mathrm{SH}^{+}$ions in our spectrum may also suggest that we have some signal contribution from thiols. Thus, a substantial percentage of our AMS sulfate signal is likely due to the fragmentation of organosulfur compounds. Organosulfur aerosols could have acted as another reservoir for S-MIF and may require less initial $\mathrm{SO}_{2}$ pressure, with possibly less restriction of $\mathrm{O}_{2}$ levels in early Earth's atmosphere than the formation of $\mathrm{S}_{8}$.

\section{Conclusions}

Our experiments found that the formation of $\mathrm{S}_{8}, \mathrm{H}_{2} \mathrm{SO}_{4}$, and organosulfur aerosols from $\mathrm{SO}_{2}$ is affected by several experimental factors: (1) initial partial pressure of $\mathrm{SO}_{2},(2)$ reducing gases present during the reaction of $\mathrm{SO}_{2}$, (3) the energy source used to initiate the reaction, and (4) the amount of water vapor present. We have summarized our conclusions in Fig. 6, modifying a figure by Ono et al. (2003) to reflect our results.
From our experiments, it appears that either high levels of $\mathrm{SO}_{2}$ or the presence of reducing gases are necessary for the formation of $S_{8}$ in the presence of water vapor and lowwavelength UV light. The water vapor levels in our experimental chamber are most likely lower than, or close to, the levels at lower altitudes in the Archean atmosphere, and levels of $\mathrm{OH}$ in our chamber are probably directly related to the amount of water vapor. However, models calculate that $\mathrm{OH}$ levels in the Archean atmosphere would have been limited by reaction with $\mathrm{H}_{2}, \mathrm{CO}$, and $\mathrm{CH}_{4}$ (Pavlov et al., 2000). The increase in $S_{8}$ with the addition of reducing gases in our experiments appears to agree with these model results. It is important to note that we did form $\mathrm{S}_{8}$ at levels of $\mathrm{O}_{2}>10^{-5}$ PAL with sufficiently large mixing ratios of $\mathrm{SO}_{2}$ or sufficient amounts of reducing gases, or both. An atmosphere with more $\mathrm{CH}_{4}$ or $\mathrm{H}_{2}$ could potentially form more $\mathrm{S}_{8}$ than one that is less reducing. The photolysis products of $\mathrm{SO}_{2}$ and $\mathrm{CH}_{4}$ can also react to form substantial amounts of organosulfur compounds. Lower mixing ratios of $\mathrm{SO}_{2}$ are required for the formation of organosulfur aerosols than would be required for $\mathrm{S}_{8}$ aerosols; 2 ppmv $\mathrm{SO}_{2}$ or below are required for organosulfur formation, while $2000 \mathrm{ppmv} \mathrm{SO}_{2}$ or above are needed for $\mathrm{S}_{8}$ aerosol formation. Thus, organosulfur aerosols could provide another reservoir for S-MIF at various oxidation levels different than $\mathrm{S}_{8}$ and $\mathrm{H}_{2} \mathrm{SO}_{4}$, and in addition can form at more reasonable levels of $\mathrm{SO}_{2}$ in the presence of $\mathrm{H}_{2} \mathrm{O}$. These experiments illustrate that the atmospheric sulfur and methane cycles may have been coupled; thus important chemistry may be missing from present models of the atmosphere of early Earth. Further work should be carried out to explore the total pressure dependence and water vapor dependence of the reactions that lead to the production of $\mathrm{S}_{8}, \mathrm{H}_{2} \mathrm{SO}_{4}$, and organosulfur aerosols.

\section{Acknowledgments}

H. Langley DeWitt was partially supported by a NASA GSRP fellowship. Christa A. Hasenkopf was supported with a National Science Foundation Graduate Research Fellowship. We gratefully acknowledge NASA Grant NNX07AV55G for funding. We thank Donna Sueper (CU-Boulder) for the data analysis software for the high-resolution AMS.

\section{Abbreviations}

AMS, aerosol mass spectrometer; HR-AMS, highresolution time-of-flight aerosol mass spectrometer; MSA, methyl sulfonic acid; $m / z$, mass-to-charge ratio; PAL, present atmospheric level; Q-AMS, quadrupole-based aerosol mass spectrometer; S-MIF, sulfur mass-independent fractionation.

\section{References}

Bekker, A., Holland, H.D., Wang, P.L., Rumble, D., Stein, H.J., Hannah, J.L., Coetzee, L.L., and Beukes, N.J. (2004) Dating the rise of atmospheric oxygen. Nature 427:117-120.

Canagaratna, M.R., Jayne, J.T., Jimenez, J.L., Allan, J.D., Alfarra, M.R., Zhang, Q., Onasch, T.B., Drewnick, F., Coe, H., Middlebrook, A., Delia, A., Williams, L.R., Trimborn, A.M., Northway, M.J., DeCarlo, P.F., Kolb, C.E., Davidovits, P., and Worsnop, D.R. (2007) Chemical and microphysical characterization of ambient aerosols with the Aerodyne aerosol mass spectrometer. Mass Spectrom Rev 26:185-222. 
DeCarlo, P.F., Slowik, J.G., Worsnop, D.R., Davidovits, P., and Jimenez, J.L. (2004) Particle morphology and density characterization by combined mobility and aerodynamic diameter measurements. Part 1: theory. Aerosol Sci Technol 38:11851205.

DeCarlo, P.F., Kimmel, J.R., Trimborn, A., Northway, M.J., Jayne, J.T., Aiken, A.C., Gonin, M., Fuhrer, K., Horvath, T., Docherty, K.S., Worsnop, D.R., and Jimenez, J.L. (2006) Fielddeployable, high-resolution, time-of-flight aerosol mass spectrometer. Anal Chem 78:8281-8289.

Domagal-Goldman, S.D., Kasting, J.F., Johnston, D.T., and Farquhar, J. (2008) Organic haze, glaciations and multiple sulfur isotopes in the Mid-Archean Era. Earth Planet Sci Lett 269:29-40.

Farmer, D.K., Matsunaga, A., Docherty K.S., Surratt, J.D., Seinfeld, J.H., Ziemann, P.J., and Jimenez, J.L. (2010) Response of an aerosol mass spectrometer to organonitrates and organosulfates and implications for atmospheric chemistry. Proc Natl Acad Sci USA 107:6670-6675.

Farquhar, J., Bao, H.M., and Thiemens, M. (2000) Atmospheric influence of Earth's earliest sulfur cycle. Science 289:756-758.

Farquhar, J., Savarino, J., Airieau, S., and Thiemens, M.H. (2001) Observation of wavelength-sensitive mass-independent sulfur isotope effects during $\mathrm{SO}_{2}$ photolysis: implications for the early atmosphere. J Geophys Res 106:32829-32839.

Haqq-Misra, J.D., Domagal-Goldman, S.D., Kasting, P.J., and Kasting, J.F. (2008) A revised, hazy methane greenhouse for the Archean Earth. Astrobiology 8:1127-1137.

Jayne, J.T., Leard, D.C., Zhang, X.F., Davidovits, P., Smith, K.A., Kolb, C.E., and Worsnop, D.R. (2000) Development of an aerosol mass spectrometer for size and composition analysis of submicron particles. Aerosol Sci Technol 33:49-70.

Jimenez, J.L., Jayne, J.T., Shi, Q., Kolb, C.E., Worsnop, D.R., Yourshaw, I., Seinfeld, J.H., Flagan, R.C., Zhang, X.F., Smith, K.A., Morris, J.W., and Davidovits, P. (2003) Ambient aerosol sampling using the Aerodyne Aerosol Mass Spectrometer. J Geophys Res 108, doi:10.1029/2001JD001213.

Kasting, J.F. (2001) Earth history-the rise of atmospheric oxygen. Science 293:819-820.

Kasting, J.F., Zahnle, K.J., Pinto, J.P., and Young, A.T. (1989) Sulfur, ultraviolet-radiation, and the early evolution of life. Orig Life Evol Biosph 19:95-108.

Lyons, J.R. (2007) Mass-independent fractionation of sulfur isotopes by isotope-selective photodissociation of $\mathrm{SO}_{2}$. Geophys Res Lett 34, doi:10.1029/2007GL031031.

Lyons, J.R. (2009) Evaluating $\mathrm{SO}_{2}$ photolysis as the source of Archean sulfur MIF. Geochim Cosmochim Acta 73:A807.

Moses, J.L., Lellouch, E., Bezard, B., Gladstone, G.R., Feuchtgruber, H., and Allen, M. (2000) Photochemistry of Saturn's atmosphere: II. Effects of an influx of external oxygen. Icarus 145:166-202.
Ono, S., Eigenbrode, J.L., Pavlov, A.A., Kharecha, P., Rumble, D., Kasting, J.F., and Freeman, K.H. (2003) New insights into Archean sulfur cycle from mass-independent sulfur isotope records from the Hamersley Basin, Australia. Earth Planet Sci Lett 213:15-30.

Pavlov, A.A. and Kasting, J.F. (2002) Mass-independent fractionation of sulfur isotopes in Archean sediments: strong evidence for an anoxic Archean atmosphere. Astrobiology 2:27-41.

Pavlov, A.A., Kasting, J.F., Brown, L.L., Rages, K.A., and Freedman, R. (2000) Greenhouse warming by $\mathrm{CH}_{4}$ in the atmosphere of early Earth. J Geophys Res 105:11981-11990.

Textor, C., Graf, H.-F., Herzog, M., and Oberhuber, J.M. (2003) Injection of gases into the stratosphere by explosive volcanic eruptions. J Geophys Res 108, doi:10.1029/2002JD002987.

Tian, F., Toon, O.B., Pavolv, A.A., and De Sterck, H. (2005) A hydrogen rich early Earth atmosphere. Science 308:10141017.

Trainer, M.G., Pavlov, A.A., Curtis, D.B., McKay, C.P., Worsnop, D.R., Delia, A.E., Toohey, D.W., Toon, O.B., and Tolbert, M.A. (2004) Haze aerosols in the atmosphere of early Earth: manna from heaven. Abstr Pap Am Chem Soc S 228:U696.

Trainer, M.G., Pavlov, A.A., DeWitt, H.L., Jimenez, J.L., McKay, C.P., Toon, O.B., and Tolbert, M.A. (2006) Organic haze on Titan and the early Earth. Proc Natl Acad Sci USA 103:1803518042.

Ueno, Y., Johnson, M.S., Danielache, S.O., Eskebjerg, C., Pandey, A., and Yoshida, N. (2009) Geological sulfur isotopes indicate elevated OCS in the Archean atmosphere, solving faint young Sun paradox. Proc Natl Acad Sci USA 106:1478414789.

Zahnle, K., Claire, M., and Catling, D. (2006) The loss of massindependent fractionation in sulfur due to a Palaeoproterozoic collapse of atmospheric methane. Geobiology 4:271-283.

Zorn, S.R., Drewnick, F., Schott, M., Hoffmann, T., and Borrmann, S. (2008) Characterization of the South Atlantic marine boundary layer aerosol using an Aerodyne aerosol mass spectrometer. Atmospheric Chemistry and Physics 8:4711-4728.

Address correspondence to: H. Langley DeWitt

CIRES

UCB 216

University of Colorado at Boulder Boulder, CO 80309

E-mail: dewitt@colorado.edu

Submitted 12 August 2009 Accepted 25 May 2010 
